XV београдска гимназија, Београд

DOI 10.5937/kultura1650319K

УДК 791.229.2:27

791.3:27

14 Жижек C.

оригиналан научни рад

\title{
TEONOUKO-ФИTO3ОФCKO
}

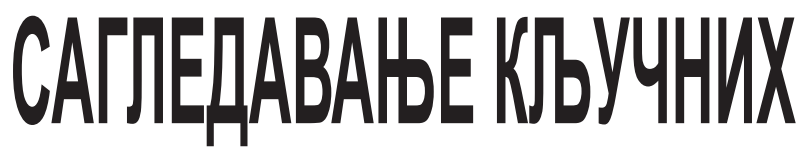
AEDOBA OИЛMA
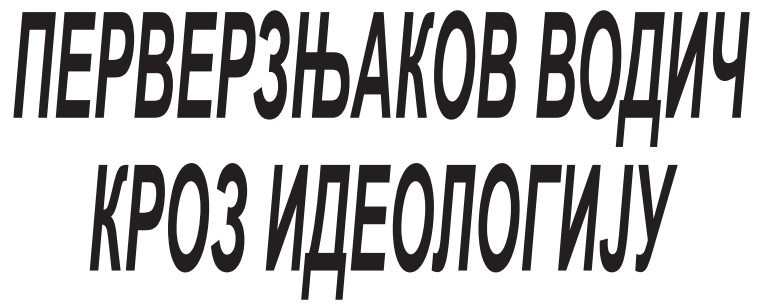

Сажетак: У овом раду се кроз теолошку призму сагледавају кључни делови филма Перверзьаков водич кроз идеологију. У првом делу обрађујемо Жижеково сагледавање Јововог и Христовог страдања као и фаворизовање постметафизичке религије - хришћанства, ито упоређујемо са третирањем теодикеје од стране Лешека Колаковског. Жижеков исказ о религијском фанатизму као религијској суспензији етичког упоређујемо са гледиштем Роуена Вилијамса да без Бога врло лако може доћи до изопачене слободе, која представља суштину дијаболичног. Напослетку бива обрађена Жижекова критика модерног конзумеризма који фаворизује уживање као облик својеврсне изопачене дужности. Грејем Ворд се усредсређује на глобални град који форсира материјални конзумеристички рај, док је духовност нешто споредно.

Кључне речи: хришћанство, атеизам, религијски фундаментализам, државни интервенционизам, конзумеризам, капитализам, град

Славој Жижек, један од најзначајних филозофа данашњице, након прве успешне сарадње са редитељком Софи Фајнс, 


\section{СЛАВИША КОСТИЋ}

која се огледа у документарном филму Перверзьаков водич кроз кинематографију (2006), у овом наставку покушао је да даิ одговор на модерни концепт идеологије. Најпре да разјаснимо сам појам первертирати, који се налази у наслову овог филма а који овде означава искривљавање наших предрасуда (а не перверзно понашање). Будући да смо се у модерни суочили са губљењем смисла и зашли у нихилизам, који је изродио озлоглашене тоталитарне режиме XX века, посредством рашчаравања дат је задатак кључним мислиоцима да нађу излаз из овог беспућа. Ово уједно даје инспирацију и за заснивање једне критичке теологије. Хришћанска теологија износи причу о Богу са позиције у којој се теолог тренутно налази, стога изношење религиозног наратива понавља и рефигурише језик, идеологије, културне претпоставке, страхове и снове о бољим временима. Жижек је у овом документарцу покушао да да одговор преко Лакановог поимања Велики Други, кључног елемента сваке идеолошке грађевине. Постоје два контрадикторна појма Великог Другог. Са једне стране, Велики Други је тајни поредак ствари: Божански ум, вера која контролише нашу судбину, али који је можда и најмање интересантан и представља аспект учинка Великог Другог преко којега добијамо значење нашега понашања. Међутим, овде треба разјаснити то да Жижек, иако се изјашњава као атеиста, уствари подржава теолошко противљење Богу класичне метафизике (тј. онтотеологије), која се идентификује са грчком филозофском категоријом „битка”, који снажно утемељује сва бића. Са те позиције Бог се поима као највише биће, causa sui, који подупире бића у целини и који осигурава објективност ствари (оно што Лакан управо и назива Велики Други). Морамо бити јасни - овде се не потенцира својеврсни атеизам, већ се указује на неадекватност метафизичког покушаја започетог са Томом Аквинским, већ да Бога можемо препознати с оне стране бића, сагласно са исказом у 1 Јн 4,8: „Бог је љубав (агапе)". На овај начин исповедамо Бога вере и тиме се ослобађамо залога онтотеологије ${ }^{1}$. За нас је интересантнији наредни аспекат Великог Другог као поретка појава: многе ствари које су забрањене, нису просто забрањене, већ се нису ни десиле за Великог Другог, што подразумева критику сваког вида тоталитаризма али и преовлађавајуће идеологије конзумеризма. Жижекова критика идеологија овде је остварена посредством модерне кинематографије, тако да је не само популаризовао своја филозофска гледишта, већ их је учинио медијски доступним за широке масе. Ограђујемо

1 Marion, J. (1991) God without Being, translated by Thomas Carlson, Chicago: University of Chicago Press, pp. 47-67. 


\section{СЛАВИША КОСТИЋ}

се од неких његових тенденциозних претеривања и не желимо да их коментаришемо, као у случају критике религиозних институција. У овом раду нас ће интересовати његово третирање хришћанства, религијског фанатизма и државног интервенционизма, али ћемо се осврнути и на модерно потрошачко друштво, суочавајући његове ставове не само са ставовима одређених теолога, већ и са мислиоцем попут Лешека Колаковског.

\section{Жижек о хришћанству}

У Первезьаковом водичу кроз идеологију Жижек обрађује хришћанство преко филма Последње Христово искушеюе (режисер Мартин Скорсезе, из 1988. године). Зашто се окренуо ка гностичком јеванђељу по Томи да би започео излагање о Христу? Жижек указује на значај хистерије преко које ми преиспитујемо наш друштвени симболички идентитет. У психоаналитичкој теорији хистерична позиција јесте сумња и то је изузетно продуктиван положај. Јединствени карактер хришћанства преноси ово хистерично преиспитивање на самог Бога као на субјекат. За Христа је у младости било трауматично искуство да призна да је он оваплоћени Бог. Жижек прави паралеле са Књигом о Јову. Јов по Жижеку јесте претеча Исуса Христа. У овој књизи обрађује се страдање праведника Јова коме Бог отима имање. Три пријатеља теолога дођу код Јова и покушавају да га убеде у вези са његовом наводном кривицом. Величина Јовова састоји се у томе што није хтео да прихвати своју кривицу и на крају књиге Бог се појављује и каже Јову да све оно што су му пријатељи рекли није истина и оцењује да је он био у праву. Катастрофе немају значења. Овде налазимо први корак у правцу тога да се патњи одузме легитимитет.

Контраст између јудаизма и хришћанства је у контрасту између анксиозности и патње. Јеврејски Бог је амбис за све остале жеље. Дешавају се страшне ствари за које је Бог одговоран али ми не знамо шта Велики Други, односно Бог жели од нас. Шта то Бог жели? Као одредницу тог трауматичног искуства Лакан користи италијанску реч che voglio - шта хоћеш? Јудаизам истрајава на тој анксиозности и Бог остаје загонетан, застрашујући. Хришћанство ту тензију разрешава љубављу, јер због љубави према нама Бог је жртвовао свога сина. То је имагинарно, чак сентиментално решење ситуације, те основне анксиозности. На крсту умире управо тај заштитник Великог Другог. Христова смрт није некакав откуп у смислу - Исус пати да отплати наше грехе. То је просто рушење Бога који је јемац смисла нашег живота. И то јесте смисао Христове реченице: „Боже 
мој, Боже мој, зашто си ме оставио?” Ово је веома значајан сегмент код Жижека који сматра да се преко разрачуњавања са моралним метафизичким Богом онтотеологије отвара простор за нову аутентичну постметафизичку религију, хришћанство које се фокусира на агапе 2 . Жижеов водич је Хегел. Хегел чита поруку крста искључиво преко кенозе, чиме се Бог испражњује. Оно што умире на крсту је сам Бог, а не само његов смртни сасуд 3 . Преко Христове смрти имамо нешто што у психоанализи зовемо субјективна деституција. Она поништава читаво поље Великог Другог. Уствари, овде Жижек интерпретира Лакана, који каже да истинска атеистичка формула није: „Бог је мртав”. Није довољно само да свесно престане да се верује у Бога, већ треба имати на уму то да је Бог престао да верује себи. Пошто је Бог идентификован са симболичким поретком, не треба веровати у Великог Другог, нити се уздати у Великог Другог који верује за мене 4 . Христова порука пред смрт је: „Ја умирем, моја смрт је радосна вест по себи, будите своји, будите у Духу Светом - што јесте заједница верних". Христос је сада присутан кроз заједницу верних. Стога је, по Жижеку, једини начин да се буде атеиста - да се претходно прође кроз хришћанство.

Свакако да је Жижек у својој материјалистичкој теологији показао интересовање за хришћанство и да је добро поставио проблем у вези са анксиозношћу повезаној с Богом као највишим бићем, која није постојала само код Јевреја, већ и код Грка. Уколико желимо да упознамо јудео-хришћанског Бога, морамо да знамо да он потврђује своје постојање захватима унутар историје и своје присуство потврђује увек у границама личног односа. Тако се открива Мојсију и разговара са њим лицем у лице као са пријатељем својим (Изл 33,11). Не бисмо могли општити са Богом када би он био тек највише биће. Бога сусрећемо онаквог какав нам у највишем смислу припада - као личност. Стога се у симболичком начину говора о Богу сусреће оно што бесконачно надилази наше искуство личности, као и оно што је највише у томе искуству, па Богу можемо рећи Ти и к њему усмерити молитву ${ }^{5}$.

2 Žižek, S. Dialectal clarity versus the Mysty concept of Paradox, in: The Monstrosity of Christ. Paradox of Dialectic? ed. Creston, D. (2009), London: The MIT Press, p. 255.

3 Цитирано код: Žižek, S. Dialectal clarity versus the Mysty concept of Paradox, in: The Monstrosity of Christ. Paradox of Dialectic? ed. Creston, D. (2009), London: The MIT Press, pp. 265-266.

4 Pound, M. Theology, in: The Žižek dictionary, ed. Butler, R. (2014), New York: Acumen, p. 247.

5 Tillich, P. (2009) Teologija kulture, preveo s engleskog Entoni Šeperić, Rijeka: Ex Libris, str. 58. 


\section{СЛАВИША КОСТИЋ}

Сада ћемо се осврнути на виђење приче о Јову а самим тим и на проблем страдања сагледан од стране Лешека Колаковског. Прво дело Колаковског које се дотиче Јововог страда-

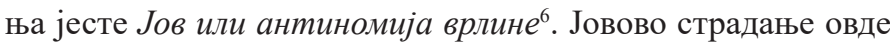
више одговара библијском извештају и одиграва се у бару Кокофли, где Господ седи док ђаво наступа као клеветник који напада праведног Јова. Овде не налазимо три теолошка пријатеља који Јову сугеришу да је због нечега згрешио, већ је Јов препуштен Божијој опклади са ђаволом. Господ, ради опкладе са ђаволом, пушта невоље на Јова: прво овај изгуби богатство, затим му деца буду побијена, трпи приговоре од стране своје жене у вези са уздањем у Бога. На крају Јов успева да победи своја искушења захваљујући својој вери у Бога, ђаво признаје победу али доноси закључак зашто је Бог уствари однео победу. Ђаво заправо делује преко материјалних ствари да би изазвао зло у духовном свету, због чега мора да познаје правилности узрочног, узајамног дејства телесне и духовне стварности, како би ову последњу разграђивао путем посредних утицаја. Бог делује непосредно у душама, па има додира са творевином коју је створио. Међутим, ђаво у таквом случају добија више, јер уска је стаза спасења, док су широка врата која воде у пропаст, што значи да ђаво не обавља посао лоше. Потом закључује да је једну душу придобио, а то је Јовова жена која је роптала на Бога. И понајвише, ђаво сматра да је Јов остао веран Богу пошто се понашао мање мисаоно, тј. поверовао је у необориву моћ начела верности и одлучио је да буде веран некадашњем заштитнику, чак и онда када се овај претвори у џелата. Из овога Колаковски закључује да се прави Господњи тријумф испољава тамо где дејствује супротно суштини или Господ односи победу утолико уколико се показује другачијим него што уствари јесте. Да би победу односио стално, он мора стално да иступа у улози злочинца, и отуда се људима који плитко мисле чини да је Господ уредио свет веома лоше. У ствари га је уредио веома мудро: он множи људске несреће јер преко њих постиже моралне победе. Када би људи били срећни, Сотона би имао мале успехе а Бог никакве. Међутим, у наредном раду, који је опет посветио проблематици у вези са Јовом, закључује да његове несреће нису одуживање дуга за некакве преступе. Јов се, такође, мири са тим да је Бог само извор мудрости и да су путеви Његови непојмљиви. Сам Бог се љути на Јовове саветнике, теологе, вероватно због тога што су, по њиховом мишљењу, Јовове патње одговарајућа отплата дуга за његове грехе. Мишљење теолога

6 Kolakovski, L. Jov ili antinomija vrline, 14 April 2015 http://www.aforizmi. org/etna/etna87/kolakovski12.htm 
које Колаковски сматра одговарајућим је у смислу да је Бог захваљујући свом свезнању природне догађаје укључио у морални поредак космоса. Они се одвијају захваљујући непобитним моћима природе, а истовремено имају морални циљ, односно не схватамо их као чуда која прекидају систем узрока и последица. Међутим, такође закључује да термини „добар” и „зао” нису емпиријске вредности, да не постоји нешто попут перцепције моралних вредности као ни интуиције зла и да људска цивилизација нема однос према питању зла, већ да је реч о мноштву непријатних утисака

Сигурно је да се Жижек не би сложио са одређеним ставовима Колаковског, чак је у једном предавању инсинуирао на овај први чланак о Јову ${ }^{8}$ и можда би Колаковског оптужио да заступа идеолошко религијско мишљење по којем верник по сваку цену треба да се узда у Бога. Жижек, уосталом, сматра да је Кьига о Јову прва критика идеологије. Савремена библијска истраживања указују на то да Христове речи: „Боже мој, Боже мој, зашто си ме оставио” у Мк. 15,34 у ствари јесу рецитовање Псалма 22,19. Исус је био побожни Јеврејин а изговарање псалама уклапа се у побожне обичаје Јевреја. Стога је Колаковски у праву када каже да је врлина верности на неки начин ирационална и да се Исус, попут Јова, уздао у начела верности према Богу, пошто ђаво обично увек има рационална објашњења. Оно што код Колаковског може бити проблематично јесте својеврсна дуалистичка слика Бога у циљу креирања модерне теодикеје. Међутим, чињеница је да су и Жижек и Колаковски у једном сагласни: нема одговора за људску патњу, а теологија понајмање треба да се бави теодикејом. Старо схоластичко теолошко решење које треба напустити јесте да је Христос страдао на крсту ради задовољења Божије правде. Склони смо томе да кажемо да је на крсту страдао Богочовек и да је Бог присутан у слави приликом страдања свакога недужног човека. Јер, сиромашан човек по хришћанству јесте онај који има одсуство наде, а нада управо јесте залог наше вере. Теолози би данас требало да своју теологију изнесу савременим језиком и да буду кадри да објашњавају религијске симболе, посебно зато што теологија може бити јако занимљива уколико се саображава модерним културним концептима. Но, проблем

7 Kolakovski, L. Lajbnic i Jov. Metafizika zla i saznavanje zla u: Da li je Gospod Bog srećan? (2013), prevela sa poljskog Biserka Rajačić, Beograd: Alef, Gradac, str. 13-18.

8 Žižek, S. The Book of Job is the great work critique of ideology, 13 April $2015 \mathrm{https}: / /$ www.youtube.com/watch? $\mathrm{v}=\mathrm{w} 0 \mathrm{jzsne} 1 \mathrm{TRI}$.

9 Погледај у: Coley, J. Н. (2009) Jesus's cry from the Cross, London: T \& T Clark. 


\section{СЛАВИША КОСТИЋ}

настаје уколико теологија следи архаични језик, који многи не разумеју, и који заправо представља језик идеологије којом се прикрива право значење религијских симбола. У том смислу Бог ће се љутити и на садашње теологе, као и у случају три Јовова теолошка пријатеља. Још један проблем који Жижек није сагледао у свом својеврсном маркионизму је да је постојала еволуција појма о Богу кроз Библију а да већ код Авраама налазимо пледоаје за једну нову визију Бога. То се огледа у Аврамовом жртвовању Исака (Пост 22, 9-13), где, уствари, он раскида у потпуности са паганском праксом, тј. са жртвовањем првенаца које је постојало у Ханану, као и да кроз своју веру у Бога Авраам показује гостољубље према странцима (Пост 19, 1-5), што представља лагани ход ка љубави која своје испуњење има кроз Христа.

Међутим, главни проблем представља то што Жижек у овом делу филма запоставља други назив за Христа, а то је Син човечји. Христос је, по јеванђељском извештају, био дубоко уверен у своју мисију у вези са идеалима хуманости. Циљ слике кушања Христовог у пустињи, коју ћемо наћи у Мт. 4, управо је тај да укаже на његову приврженост самоме Богу од почетка његове мисије. Еманципацију људи проповеда у две најзначајније заповести: љуби Бога и ближњега свога као самога себе. Кроз сједињење две природе, означава се управо идеал сарадње Бога и човека. На основу те христолошке поставке, можемо рећи да се оправдавамо пред Богом кроз бригу о другом човеку, преко чега пројављујемо идеале братства и хуманости, што су били и идеали комунизма, али и модерне теорије о људским правима. Управо комунизам преузима тај концепт од хришћанства. Хистерија и преиспитивање нису категорије које можемо применити на Христа, пошто је он одувек и био уверен у својој мисли да је хуманизам $=$ синовство Божје и то је сматрао темељем своје духовне револуције. Жижеков исказ о томе да је Христос поставио темеље атеизма, треба преформулисати у тезу о постављању смисла истинског хуманизма: не може се бити истински хуманиста ако ниси прешао пут хришћанства! Порука Христа његовој заједници била би следећа: будите у Светом Духу и волите се међу собом управо зато да бисте показали да сте синови Божији и слободу наспрам Великог Другог. Из свега овога происходи да је веома важно каквог Бога исповеда конкретна верска заједница. 
СЛАВИША КОСТИЋ

\section{Жижекова критика религијског фундаментализма и државног интервеничионизма}

Једна од битних тема овог документарног филма јесте религијски фундаментализам. Осврнувши се на тезу Достојевског по којој: „Ако Бога нема, све је дозвољено”, коју Жижек сматра апсолутно погрешном, прихвата се Лаканове преправке „Ако Бога има, све је дозвољено не само онима који верују у Бога, него и онима који себе сматрају директним инструментом Божије воље.” Такав закључак износи да би указао на проблем исламског тероризма. Уколико посматрамо себе као инструменте Божије воље, онда сви уски, ситни морални обзири - нестају. Уствари, они прате первертирану верзију онога што је Кјеркегор назвао „религијска суспензија етичког". Тако раде сви тзв. религијски фундаменталисти, али не само они. Сваки облик такозваног тоталитаризма то ради, чак иако се представља атеистичким. То се доводи у везу са стаљинизмом, у којем, ако се пажљиво погледа субјективно искуство лидера, видимо да то није позиција осионог господара, већ да се он пројављује као слуга свога народа који пројављује Великог Другог. Тај Велики Други има у стаљинизму многе термине, међу којима је најважнији: нужност историјског напретка ка комунизму. Комуниста просто доживљава себе као инструмент чија је функција да оствари историјску нужност. Народ чији је инструмент тоталитарни вођа никада не представљају стварни појединци, групе људи и слично. Увек може да се каже то су појединци и да то није прави народ. Када би лидера оптужили за почињене злочине, следио би стандардни стаљинистички изговор да свој задатак схвата као своју дужност. Но, зашто смо, по Жижеку, сведоци религијског или етички оправданог насиља? Зато што живимо у ери коју бисмо могли назвати постидеолошком.

Роуен Вилијамс, англикански теолог, тумачећи реченицу: „Ако нема Бога, све је дозвољено” указује на то да уколико одбацимо Бога онда его заузима то упражњено место на којем је био Бог. „Све је допуштено” не значи само да је сваки злочин легитиман, него да свако вредновање мора доћи из ,ја" као извора одлучивања. Ако је свету без Бога све дозвољено, дозвољена је и љубав према Богу и ближњему, али зато недостаје било какво упориште такве љубави у самој природи ствари. То укључује виђење света који је морално индиферентан, у којем садистичка суровост стоји раме уз раме са било којим другим понашањем и виђење себе као неког ко је осуђен на безгранично понижење, бол 


\section{СЛАВИША КОСТИЋ}

и одбаченост. Нема Бога који би пресудио и тај свет је морално неутралан (па зато и страшан). Уколико нема ничег темељног, ничега на чему почивају значења у људском свету, ниједно деловање није само по себи вредније од било којег другог. По Вилијамсу, без Бога врло лако може доћи до изопачене слободе, која представља суштину дијаболичног. Апсолутна слобода завршава се апсолутним деспотизмом, пошто већина људи није способна да рационално користи слободу. Уколико признамо да Бога нема, нема никакве силе која би била изнад људске воље. А шта нам то неопозиво показује снагу људске воље? Способност човекова да уништи себе као најчистији могући начин неразумног одређења ${ }^{10}$.

Међутим, Вилијамс се не осврће на психолошки профил религијског фундаменталисте, као ни Жижек. Код Жижека све је окренуто ка Великом Другом. По Старку и Бејнбриџу, на процес настанка необичних верских убеђења у великој мери утиче психопатолошки фактор. Према психопатолошком моделу, душевно оболеле особе измишљају необичне компензаторе и прихватају их као награде. Душевно обољење ослобађа појединца конвенционалних схватања и омогућава значајан ниво креативности. Они могу да пролазе кроз фазу болести у којој испољавају висок ниво креативности и новаторства и да стварају сасвим нове компензаторе и религијске идеје, које потом, кад се врате у стање нормалности, успевају да саопште другима и учине да оне у религијској комуни буду прихваћене ${ }^{11}$. Пошто они испољавају неконвенционалне облике понашања и производе идеје, привлачни су одређеним групама људи. У већој мери то се може односити и на тоталитарне лидере, јер су у многим случајевима они били поремећене личности. Ово је нешто што је било познато у православној монашкој литератури: танка је линија између особе која је у прелести (обмана, фантазија као продукт помрачене демонизоване свести) и особе која је доживела мистично искуство. Стога треба направити демаркациону линију између просветљеног верника који живи сагласно са начелима своје вере и верског фундаменталисте, који искривљује своју веру.

Жижек указује на то да се у филму Мрачни витез (режисер Кристофер Нолан, реализован 2009. године) лаж уздиже као општи друштвени принцип, као принцип организације нашег друштвеног и политичког живота. Тај филм указује на

10 Вилијамс, Р. (2014) Достојевски, Превела с енглеског Ангелина Мишина и Павле Рак, Београд: Хришћански културни центар др Радован Биговић, Zepter Book World, стр. 92-122.

11 Hamilton, M. (2003) Sociologija religije, preveo s engleskog Đorđe Trajković, Beograd: Clio, str. 407-408. 
принцип по којем наше друштво може да остане стабилно и може да функционише само ако се заснива на лажи. Говорити истину (а отелотворење истине је Џокер), условљава поремећај и распад друштвеног поретка. Идеја је та да ако јавност схвати како је корумпирано само језгро нашег правног система, онда ће све пропасти и зато нам треба лаж да би се одржао ред. То је, по Жижеку, стара конзервативна мудрост коју су одавно утврдили филозофи, почев од Платона, а затим Имануел Кант, Едмунд Бурк. Они пролонгирају идеју да је истина прејака. Политичар треба да буде циник, који мада зна шта је истина, говори људима оно што Платон назива „племенитом лажи”. Међутим, проблем у овоме јесте што Жижек није даље разрадио ову тезу и проширио је у вези са моћи информације као и са феноменом савремених друштвених мрежа, као битним фактором који утиче на формирање јавног мњења, утицајним на свеопшту атомизацију субјеката, тј. на њихово утапање у масу. У овоме се могао користити филмским остварењима попут: Мрежа (режисер Ирвин Винклер, реализован 1995. године) и $P a-$ том против истине (режисер Бери Левинсон, реализован 1997. године).

Следећи битни сегмент овог документарца јесте Жижеково освртање на филм Ајкула (режисер Стивен Спилберг, реализован 1975. године) и проблем превладавања мноштва страхова преко обједињавања у заједничком именитељу, који овде представља ајкула. Шта овде представља ајкула? По Жижеку, ајкула обједињује мноштво страхова који постоје код људи. Плашимо се имиграната, које сматрамо мање вредним, да нас не нападну, опљачкају, да ће нам силовати децу. Бојимо се природних катастрофа. Бојимо се корумпираних политичара, великих компанија које раде са нама шта хоће. Функција ајкуле у овом филму јесте да уједини све ове страхове, тако да све страхове доживљавамо као један. Најекстремнији случај идеологије у историји човечанства, нацистички и фашистички антисемитизам деловао је на исти начин. Фашизам ствара идеолошку причу која објашњава како су ствари у друштву кренуле наопако, не као последица тензија својствених развоју друштва, већ због страног уљеза, у овом случају Јевреја. Идеологија у овом случају функционише као нека врста филтера, као оквир и када погледамо исту обичну стварност кроз тај оквир, све се мења. Оквир, заправо, не мења ништа. Оквир само отвара амбис сумње. Ово је типично за расизам, који је усредсређен на покушај да се замисли како тај други ужива у тајним весељима јер у расизму тај други није једноставно непријатељ. Обично је удружен са неким посебно первезним уживањем или обрнуто, тај други можда покушава да украде наше 


\section{СЛАВИША КОСТИЋ}

уживање и, како се обично тврди, да угрози наш начин живота. Затим имамо кључни елемент нациста - солидарност народа. Ако мислимо на Volksgemeinschaft, јединствену заједницу људи где је непријатељ аутоматски страни уљез, у том случају смо у нацизму.

Међутим, Жижек овде није до краја разјаснио проблем нацизма. Адорна можемо узети као кључни водич за објашњавање нацистичке идеологије. По њему фашизам врши експропријацију несвесног помоћу друштвеног надзора, уместо да субјекти постану свесни свог несвесног. Теорија о психолошком осиромашењу субјекта који се предао објекту, а објекат поставио на место свог најзначајнијег састојка над-ја, готово видовито антиципира постпсихолошке, деиндивидуализоване социјалне атоме фашистичке гомиле. У тим друштвеним атомима превазићена је психолошка динамика образовања маса и престала је да буде реалност. Како код вођа, тако и код идентификацијских чинова маса, у њеном тобожњем беснилу и фанатизму, ради се о истоветној непристрасности/театралности. Једнако као што људи дубоко у себи заиста не верују да су Јевреји ђаволи, они, такође, не верују сасвим ни у вођу. Са њим се они идентификују, али ту идентификацију само глуме, инсценирају своје одушевљење и тако учествују у представи свог вође ${ }^{12}$. Овде Жижек замера Адорну што није узео у обзир кључну чињеницу да је идеологија, у извесном смислу, увек материјална, дискурзивна пракса, организована у идеолошким апаратима државе, пракса којој је својствена перформативна снага, тј. снага која сама успоставља реалност о којој говори, пошто сама идеолошка пракса низом перформативних аката успоставља то органско јединство народа: учествовати у фашистичком идеолошком ритуалу значи доживети јединство народа ${ }^{13}$. Међутим, ни код Жижека ни код Адорна не налазимо која би постојећа демократска структура државе помогла у излажењу из накарадних идеологија 20. века.

Демократија, по Стенлију Хаервасу, треба да буде усредсређена на заједничко ангажовање свих грађана, а уместо тога је политичка лојалност усредсређена на заједничко поштовање силе, што је условило појаву бирократије ${ }^{14}$. Нажалост, када су хришћани поистоветили политику са силом и приписали цркви позитивну форму политике, онда је црква

12 Adorno, T. (1973) Die Freudsche Theorie und die Struktur der faschistischen Propaganda (1951), in: Kritik. Kleine Schriften zur Gesellschaft, Frankfurt: Suhrkamp, pp. 63-65. Цитирано код: Žižek, S. (1984) Birokratija i uživanje: Beograd, str. 17.

13 Žižek, S. (jun 1984) Birokratija i uživanje: Beograd, str. 19.

14 Hauerwas, S. (2007) State of University, Blackwell Publishing, p. 160. 
одбила да призна снагу која проистиче из њених чланова, па је користила и секуларну силу да би обезбедила правоверје. Хаервас сматра да треба раскрстити са демократијом као са обликом рационалне дезорганизације која је представљена кроз две политике: прву политику постављају експерти који се боре за то да буду научни и рационални, док са друге стране имамо политику ирационалне масе, којом се управља помоћу манипулисаних слика, контролисаних информација, фанатизма и перверзног страха. Таква политика тежи да ускрати историју, партикуларност и разлику и стога је треба дефинисати као политику без меморије. Зато нам је потребна политика сећања, која би нам омогућила да повежемо прошло и садашње искуство у процесу обнове политике ${ }^{15}$. Значајне политичке форме су, по Хаервасу, настале не од спекулације филозофа, већ од актуелног искуства људи које им је опскрбило парадигму за њихове шире друштвено искуство. У нашем савременом контексту није нам потребна морална реторика, већ морална искуства заједнице ${ }^{16}$. Са оваквим виђењем демократије се у потпуности слажемо.

\section{Критика идеологије модерног конзумеризма}

Сада долазимо до критике потрошачког друштва. По Жижеку, још је Маркс одавно нагласио да роба није само прост објекат који купујемо и конзумирамо. Роба је предмет пун теолошког, чак метафизичког значења. Она увек одражава неку невидљиву надмоћ. Као пример тога наводи рекламе за кока-колу у којој се отворено позива на одсутни, невидљиви квалитет. Жижек сматра да се у нашем постмодерном друштву захтева да уживамо. Уживање постаје нека врста чудне, изопачене дужности. Најбољи пример имамо у реклами за кока-колу - што је више пијемо, више имамо жељу да је пијемо. Најнепожељнији исход жеље јесте да је испунимо, потпуно задовољимо и да више не желимо. Најтужније од свих искустава јесте губитак саме жеље.

Модерни капитализам, по Жижеку, почива на нестабилности. Капитализам има чудну религијску структуру коју покреће апсолутни захтев: капитал мора да циркулише, да се умножава и увећава. Зарад умножавања се жртвује све почевиши од људског живота па до природе. Друга страна капитализма је пропагирање кризе. Управо зато изгледа да је готово неуништив. Међутим, криза за њега није сметња.

$\overline{15 \text { Исто, стр. 162-163. }}$

16 Hauerwas, S. (1970) Politics, Vision and the Common Good, Cross Current 20 No. 4, p. 410. 


\section{СЛАВИША КОСТИЋ}

То је оно што га тера напред, да се стално усавршава и непрестано самообнавља новим производима.

Грејем Ворд, један од главних представника радикалне ортодоксије, усредсређује се на модерни град, који представља место где имамо скупину свих жеља и где се оне могу остварити. Уствари, такав космополитски град више не означава место које треба да нас усмери ка будућем рајском врту, већ је то град без цркве. Данашњи космополитски град као симбол конзументског друштва је, по Ворду, имао неколико фаза кроз модерну историју: у ренесанси то је трговачки град; у индустријској револуцији то је конкурентски индустријски капиталистички град; половином XX века то je корпорацијски монополистички град. Садашње градове карактерише страх од социјалне кастрације, која се посебно оцртава у могућности да будемо одбачени или искључени из нових искустава, чак иако су наше фантазије продукт различитих симулакрума. Уствари, то нам се указује кроз различите призме - неконтролисана капиталистичка похлепа, страховита насиља настала услед конкурентности и изразити нихилизам, који наглашава празнину бића сведених на конзументе. Са успоном произвођачког конзумеризма, градови су постали секуларна места, у којима се искључиво подстиче производња добара зарад конзумеризма и у којима нема места духовности ${ }^{17}$. Западно хришћанство је у великој мери одговорно за стварање модерног конзумеризма. У новом веку, приликом откривања Америке, формиране су две визије Еденског врта: прву карактерише стање невиности, где су људи племенити и благонаклони према свом материјалном стању (Кристофер Колумбо говори о окружењу у којем су се Индијанци налазили и како они воле свог ближњег), док други материјални рај представља неизмерни извор племенитих метала и драгог камења. Прва визија је морална и духовна, друга је културна и економска. Заједно, оне сугеришу да је материјално богатство физички одраз духовног богатства. Прва визија води ка новој безазлености, док друга води ка материјалном рају доступног богатства, неслућене потрошње као и обзнањивању спектакуларне моћи и величанства које у то време поседује краљ ${ }^{18}$. Материјално виђење раја условило је појаву капитализма. Ова визија на крају рађа Марксово виђење комодификације. Комодификација, по Марксу, има религијске корене због тога што фаворизује материјалне услове за социјализацију. По Марксу, капитализам производи свет метафизичких рафинираности и

17 Ward, G. (1999) The secular city and the Christian corpus, Cultural Values Vol. 3 No 2, pp. 145-149.

18 Ward, G. (2003) True Religion, Blackwell Publishing, pp. 37-40. 
теолошких финеса у којем су све ствари потчињене ауторитету универзалног комодитета - новца. Новац није регулативан, већ конститутиван трансцедентални елемент. У религијском свету вредности он носи маску антихриста. Новац не представља само пројаву вредности, попут других роба. То је форма пројаве вредности свих роба. Оно што узрокује моћ капитализма је трговина посредством лоше вере, која пролонгира поданичку вредност, да би преко завођења водила ка мантри кредита ${ }^{19}$. По Ворду, као и по Хаервасу, у садашњем прогресивном капитализму једина нада за опоравак лежи у заједницама које су засноване на тео-логици вере - разумевању које се заснива на прихватању доктрина и дисциплина верујуће заједнице ${ }^{20}$. Приликом сагледавања ове две перспективе можемо доћи до закључка да Жижек већи акценат даје захтеву постмодерног друштва за уживањем и кључном циљу капитализма да непрестано умножава нове производе. Ворд већи акценат придаје космополитском граду као симболу конзументског друштва. У таквим градовима искључиво се подстиче производња добара зарад конзумеризма и у њима нема места за духовност. Иако Ворд једини излаз види у заједницама које су засноване на тео-логици вере, сматрамо да у њима треба ојачати праксу која би била заснована на истинском преображају појединца.

\section{Закључак}

Како ствари стоје у данашњем постидеолошком друштву? Ханс Кинг нам са правом указује на то да је пољуљана идеологија технолошке еволуције, да сама себе води ка хуманости. Модернизација, индустрализација, ако то сагледавамо из историје капитализма, представља дезинтеграцију старих стабилних односа и подразумева друштвене сукобе. Технолошки процес који је достигао пуни замах измиче свакој контроли, довољно је чути најновије изјаве Стивена Хокинга. Са овладавањем природом долази и њено уништење. Са глобалном комуникацијом наступа све већа зависност од мултинационалних корпорација. Ширењем демократије долази до више уједначавања социјалне контроле путем друштва и његових снага. Са напредном науком, раме уз раме, иде и истанчаније експериментисање са људском природом, нпр. генетске манипулације. Укратко, имамо напредак који делује разарајуће, рационалност са цртама ирационалног, хуманизацију која води ка нехуманом - еволутивни

19 Ward, G. (Summer 2003) The Commodification of Religion or the Consummation of Capitalism, The Hedgehog Review, pp. 55-59.

20 Ward, G. (2003) True Religion, p. 134. 


\section{СЛАВИША КОСТИЋ}

хуманизам чија је нежељена, но фактичка последица рашчовечење човека.

Све ово је подлога за разне накарадне идеологије. Жижек је у праву: људи на неки начин уживају у својој идеологији. Они су чак свесни да добровољно живе у лажи. Истина може да разбије многе илузије. Искорачење из идеологије болно је искуство. Било да је у питању тоталитарни систем, постмодерно друштво... Људи више немају ауторитете, смисао и значење. Посебно се то огледа у разматрању медија: како Липовецки наводи, сваких шест месеци изнова се откривају нове вредности, осцилирајући од религије до породице, од традиције до романтизма, у општој равнодушности која се састоји од радозналости и толеранције ${ }^{21}$. Показало се у пракси да хришћанство које ћутке прихвата да је Бог оруђе које нам служи за одбрану ствари попут доктрине, идеологије или политичке партије, јесте маскирано безбожништво. Но, настаје други проблем, који су уочили Роуен Вилијамс и Колаковски: упорно смо молили Бога да напусти свет. То је и учинио на наш захтев. Иза њега је остала зјапећа празнина. И даље се молимо тој празнини, ништавилу ${ }^{22}$. Да ли је то доказ непостојања Бога? Бог који функционише као магична сила која служи нашим преким потребама у бити никада није ни била Бог хришћанске вере или Бог неке велике религије, чак ни онда када се народна религиозност хранила таквом врстом представа. Бог се може одбацивати као морална опасност, негирати као биће неприхватљиво за разум, али то што се Бог не може заборавити чини га присутним чак и када је одбачен. Присуство или одсуство Бога састоји се у вери или у невери.

Жижек сматра да се приближавамо нултној тачки. Нешто се мора променити. Међутим, у исто време, сматра да је боље не чинити ништа него се упуштати у изоловане активности чија је коначна сврха да систем боље ради. Претња данас није активност већ псеудоактивност, захтев да се буде активан, да се учествује, да би се маскирало то да се заправо ништа не дешава. По Жижеку, потребан је само мали помак у односу на досадашњу перспективу, као и то да људи схвате да засипање власти субверзивним захтевима (еколошким, феминистичким, антирасистичким, антиглобалистичким) служи томе да би се машина и даље одржавала ${ }^{23}$. По нама

21 Липовецки, Ж. (2011) Доба празнине, превела са француског Ана Моралић, Нови Сад: Издавачка књижарница Зорана Стојановића, стр. 53.

22 Kolakovski, L. (2013) Da li je Gospod Bog Srećan? Beograd: Alef, Gradac, str. 59.

23 Žižek, S. Humanitarizam je Laž! 16 april 2015 http://blog.b92.net/text/2462/ Zizek\%3A-Humanitarizam-je-laz/ 


\section{СЛАВИША КОСТИЋ}

тај мали помак једино се може остварити тако што се субјекат слободног избора мора вратити моралном искуству заједнице, а не да се заснива на моралној реторици.

\section{ЛИТЕРАТУРА:}

Вилијамс, Р. (2014) Достојевски, Превела са енглеског Ангелина Мишина и Павле Рак, Београд: Хришћански културни центар Др Радован Биговић, Zepter Book World.

Hamilton, M. (2003) Sociologija religije, preveo sa engleskog Đorđe Trajković, Beograd: Clio.

Hauerwas, S. (Fall 1970) Politics, Vision and the Common Good, Cross Current $S 20$ No. 4 (Fall 1970), pp. 399-414.

(2007) State of University, Blackwell Publishing.

Coley, J. H. (2009) Jesus's cry from the Cross, London: T \& T Clark.

Kolakovski, L. (2013) Da li je Gospod Bog srećan?, prevela sa poljskog Biserka Rajačić, Beograd, Alef, Gradac.

Jov ili antinomija vrline, 14 april 2015 http://www.aforizmi.org/etna/ etna87/kolakovski12.htm

Žižek, S. (jun 1984) Birokratija i uživanje, Beograd.

Dialectal clarity versus the Mysty concept of Paradox, The Monstrosity of Christ Paradox of Dialectic? Edited by Creston Davis (The MIT Press, 2009), pp. 234-307.

Humanitarizam je Laž! 16 april 2015 http://blog.b92.net/text/2462/Zizek\%3A-Humanitarizam-je-laz/

The Book of Job is the great work critique of ideology, 13 April 2015 https://www.youtube.com/watch?v=w0jzsne1TRI .

Липовецки, Ж. (2011) Доба празнине, превела са француског Ана Моралић, Нови Сад: Издавачка књижарница Зорана Стојановића.

Marion, J. (1991) God without Being, translated by Thomas Carlson, Chicago: University of Chicago Press.

Pound, M. Theology, in: The Žižek dictionary, edited by Butler, R. (2014), New York: Acumen, pp. 246-249.

Tillich, P. (2009) Teologija kulture, preveo s engleskog Entoni Šeperić, Rijeka: Ex Libris.

Ward, G. (2003) True Religion, Blackwell Publishing.

The Commodification of Religion or the Consummation of Capitalism. The Hedgehog Review/ (Summer 2003), pp. 50-65.

(1999) The secular city and the Christian corpus, Cultural Values Vol. 3 No. 2, pp.140-163. 
СЛАВИША КОСТИЋ

\author{
Slaviša Kostić \\ XV Belgrade Gymnasium, Belgrade \\ THEOLOGICAL-PHILOSOPHICAL PERCEPTIONS OF \\ THE KEY PARTS OF THE MOVIE \\ THE PERVERT'S GUIDE TO IDEOLOGY
}

\begin{abstract}
In this work we tend to give a theological reflection on the key parts of the movie The Pervert's Guide to Ideology. Through his views on Christianity by Passions of Christ, Žižek favours a radical break out with the Old Testament's anxious perception of God, which is dismissed by post metaphysical religion - a Christianity that concentrates on agape. On the other side, Kolakovski elevates the principle of loyalty in suffering and tends to emphasize that faith is in fact irrational. According to Kolakovski, God accomplishes his triumph showing himself different that he is. Žižek points that religious fanaticism begins as religious suspension of the ethical. Rowen Williams, on the other side, thinks that without God we easily adopt pervert freedom, which presents the essence of the diabolical. According to Žižek, modern capitalism has a sort of religious structure, which is powered by absolute demand: capital must circulate, multiply and progress. Graham Ward concentrates on the vision of a postmodern city that represents a place in which all desires are concentrated and may be realized. In fact, such a cosmopolitan city is no more a place in which to find heavenly direction, but a city without the church.
\end{abstract}

Key words: Christianity, atheism, religious fundamentalism, state intervention, consumerism, capitalism, city 